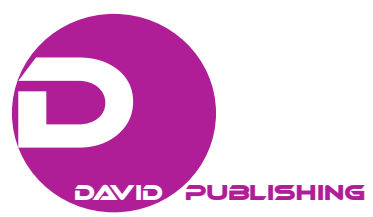

\title{
Pro-Poor Tourism: Critical Perspective and Implications for Future Research
}

\author{
Kennedy K. Akrong \\ University of Lapland, Rovaniemi, Finland
}

\begin{abstract}
Tourism is viewed as a medium to reduce poverty. The pro-poor tourism (PPT) approach has therefore emerged as the medium for tourism development to influence poverty reduction. The approach stresses on tourism development in ways to accrue net benefits to the poor through diverse strategies including those that generate employment opportunities, infrastructural development, and skills enhancement of locals in entrepreneurial activities. Also stressed is the inclusion of the poor in tourism decision making. While the pro-poor tourism approach has gained scholarly attention, much of these studies turned to assessed PPT impacts on poverty reduction in communities with limited discussion on products development. Yet, product development is considered to be the means by which tourism can contribute to local economic development and by extension, poverty reduction. This paper examines the PPT concept and argues for PPT works to examine how products are develop to influence poverty reduction with recommendations of making PPT work for the poor. This follows with implications for further research works on PPT and its development.
\end{abstract}

Keywords: pro-poor tourism, destination development, branding, marketing, pro-poor tourism partnership

\section{Introduction}

Tourism development has been regarded as a means for poverty alleviation especially for developing countries (Sharpley \& Naido, 2010; Mungand, Sahli, \& Smith, 2010; Anderson, 2015). As a consequence, the concept of pro-poor tourism (PPT) has been proposed in the late 1990s as the medium for tourism development to influence poverty reduction (Ashley, Dilys, \& Godwin, 2001).The PPT concept was subsequently adopted by non-governmental organizations and international development organizations, including the United Nations through the implementation of tourism initiatives meant to reduce poverty in developing countries (UNWTO, 2017; Hummel \& Dium, 2012; Chok, Macbeth, \& Warren, 2007; Godwin, 2008).

The origin of the PPT concept has been traced to a report by the United Kingdom's Department for International Development. The report examines ways UK's outbound tourism could contribute to poverty reduction in some developing countries (Ashley, Roe, \& Godwin, 2000; Godwin, 2008; Harrison, 2008; Mahony \& Zyl, 2002). The Pro-Poor Tourism Partnership (PPTP) was subsequently established to promote the development of PPT. The PPTP consists of the Overseas Development Institute (ODI), the International Institute for Environment and Development (IIED), and the Center for Responsible Tourism (CRT) (Mahony \& Zyl, 2002; Ashley \& Godwin, 2007). PPT prospect of becoming a source for poverty reduction is attributed to a

Kennedy K. Akrong, Ph.D. student in Tourism Research, Multidimensional Tourism Institute, University of Lapland, Rovaniemi, Finland. 
number of reasons. Firstly, tourism's potentials to provide markets for goods and services have been emphasized as opportunities for the economically poor to be employed through the sale of goods and services. Secondly, tourism is seen as an opportunity that can diversify local economies especially at impoverished destinations. Thirdly, it is argued that tourism is labour intensive as compared to other non-agricultural activities and can therefore employed many including women who are economically disadvantaged. Fourthly, emphasized is placed on the increasing growth rate of tourism in low income countries as significant to contribute to pro-poor tourism development (Ashley et al., 2000; Godwin, 2008).

The Pro-Poor Tourism Partnership (PPTP, 2004) advanced three strategies by which tourism can be developed to generate net benefits for the poor. The first focuses on economic strategies that expand local employment opportunities and wages, development of collective income sources through fees, revenue shares, equity dividends, and donations, while also expanding local opportunities through services such as food production and supplies, guiding, and sales of handicrafts. The second stresses on strategies that generate non-livelihoods opportunities through means such as skills development of locals in entrepreneurship, including strategies that address negative social, cultural, and environmental impacts of tourism. Local community access to infrastructure and services such as roads, communications, healthcare, and transport are stressed. The third emphasizes exchange of information and communication among stakeholders in formulating, implementing, and reforming policies. Involvement of the poor in these decision making processes through a supportive policy framework has been emphasized. Partnerships between all the stakeholders are also necessary and view to be significant in achieving the objectives of PPT. In summary, PPT strategies aim to assist the poor to benefit from tourism in diverse ways and through diverse strategies and collaboration of all the actors involved in PPT development. Summary of these strategies is represented in Table 1.

Table 1

Types of PPT Strategies

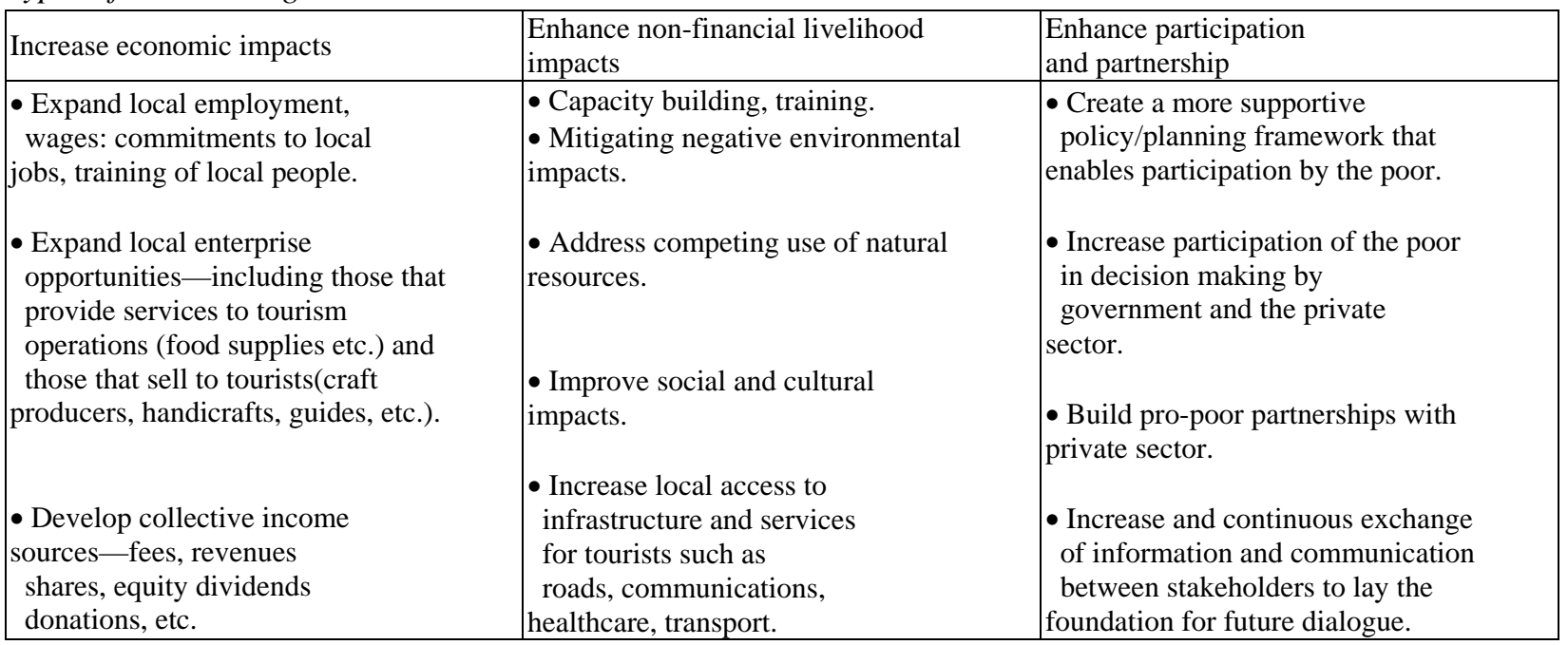

Source: Pro-Poor Tourism Partnership (PPTP) (2004).

Despite the normative intension of PPT of helping the poor, its significance to poverty reduction has been doubted. Critiques for example regard PPT as an outgrowth of neoliberal ideology which satisfies the economic interests of commercial establishments and private entrepreneurs in tourism against the interests of the poor and 
communities (Scheyvens, 2009; Chok et al., 2007). In essence, critics doubt if indeed the private sector can be committed to PPT goals (Scheyvens, 2009). In order for PPT to address poverty, it is claimed that the PPT approach should aim at structural change, redistribution of wealth and resources and tackling uneven power relations within the global political economy and national systems (Harrison, 2008). Also, critiques have argued that PPT lacks a pragmatic and theoretical focus on sustainability of tourism because of its anthropocentric bases and a lack of concern for eco-centric challenges of the poor and their communities (Chok et al., 2007). In addition, PPT has been criticized for being "narrow and parochial" because it much focused on the poor suggests other locals at destinations are precluded to gain from PPT development (Harrison, 2008, p. 860). Harrison (2008) further doubts the significance of PPT in reducing poverty on the basis that PPT projects have failed to generate sufficient benefits for poor people and communities; he however acknowledged the effort of PPT proponents in bringing poverty issues into tourism.

In view of the above criticisms, PPT proponents insist tourism has the potential to contribute to poverty reduction. As stressed, the main priority of PPT is to ensure tourism accrues nets benefit to the poor at destinations. Therefore, even if the rich benefits more from PPT projects than the poor and the poorest segments of society, tourism remains pro-poor so far as the poor gains net benefits (Ashley et al., 2001). Indeed, for tourism to benefit the poor, PPT advocates have called for government intervention through redistribution policies (Meyer, 2009). It is also stressed that PPT is not a theory for sustainable tourism development. Neither was the approach developed to ravage neoliberalism but rather to enable tourism contributes to the wellbeing of poor people through practical methods (Meyer, 2009; Godwin, 2008). In further response, Godwin (2008) argued that most of the criticisms against PPT approach are inaccurate as they are based on misapplication of PPT principles by some non-governmental organizations. And yet, current studies on PPT have much assessed tourism impacts on poverty reduction at destination with little focused on product development and the processes of PPT. This is a paradox since products development has been recognized as the anchor for poverty reduction and local economic development (Medina-Muñoz, Medina-Muñoz, \& Gutierrez-Perez, 2016; Pedrana, 2013). PPT proponents also recognized the importance of product development in achieving the objectives of PPT as they acknowledged that pro-poor tourism worked well at developed or developing destinations (Ashley \& Roe, 2002; Ashley et al., 2001).

As a point of departure, this paper argues for PPT studies to focus on the development process of products at destinations to understand destinations capabilities as means for PPT development. This focus on products development will extend knowledge on the construct of PPT at destinations and raise awareness about how researchers can further contribute to address emerging challenges hindering tourism development to be pro-poor. The next section explores how PPT emerges by discussing the context in which tourism was considered important for poverty alleviation.

\section{Tourism-Poverty Relation: The Context}

The relationship between tourism and poverty reduction can be traced to the post-war era in the 1960s where tourism became a development strategy for many of the developing countries (Croes, 2014). Foreign exchange earnings, employment generations, and multiplying effects are the economic benefits of tourism expected to stimulate economic growth and development in these countries (Telfer, 2009; Fletcher, 2009; Mawforth \& Munt, 2016; Sharma, 2004; Brohman, 1996). It was further believed tourism earnings together with export of non- traditional exports in the developing world would ensure macroeconomic stability in these 


\section{PRO-POOR TOURISM: CRITICAL PERSPECTIVE AND IMPLICATIONS FOR FUTURE RESEARCH}

countries through the enhancement of balance of trade and payments, including access to international loans and investment capital (Brohman, 1996). Although tourism and poverty has rarely been linked from this observation, Harrison (2008) notes the idea of using tourism for poverty reduction was indirectly highlighted through the argument that tourism is a potential for economic growth as well as job creation.

With the focus on economic growth, the modernization paradigm of development has been identified as the main school of thought influencing tourism development for economic development (Telfer, 2009; Scheyvens, 2007; Sharpley, 2010; Spenceley \& Meyer, 2012). The modernization paradigm considers the benefits of economic growth as the main driver that enables western societies to progress from a traditional to a modern society with increased level of mass consumptions (Telfer, 2009). It was assumed the application of the paradigm in developing countries would enable them to modernize similarly as western nations through the benefits of economic growth. It is believed benefits generated by economic growth would enhance economic wealth of all classes of people, including the poor (Telfer, 2009 after Rostow, 1960). In this context, tourism was viewed as the means to modernize developing nations as summarized by Sharpely that:

"the perceived developmental contribution of tourism through, for example, foreign exchange earnings, the multiplier concept and backward linkages throughout the economy are, firmly embedded in modernization theory”. [This in the case of tourism means that] "Development is assumed to occur as a result of the economic benefits that diffused from growth impulses (the tourism sector) or growth poles (resorts)”.(2000, p. 4)

However, economic resources generated from tourism failed to impact on the wellbeing of populations in the developing world through the 1960s and the 1970s (Brohman, 1996). This was attributed to unequal distribution of benefits as well as financial leakages by foreign corporations and private individuals investing in the tourism sector (de Kadt, 1979; Brohman, 1996; Britton, 1982). It was therefore argued that tourism growth and increase in economic opportunities are not enough to generate wealth without equal distribution of the material benefits generated within the poorest section in the developing countries (de Kadt, 1979). Beyond tourism, the general focus on economic growth as a development goal has widely failed to enhance the wellbeing of people across the countries of the south. This led to the view that economic growth as a development option is not sufficient to drive the development efforts of emerging nations (Desai \& Potter, 2002). A new focus within the development discipline emerged in the 1980s and early 1990s. Marks and Andreassen (2006) note a shift from growth model of development to human development. Development theorists followed with ways to enhance human development. Among these theorists was Friedman (1992) who argued that development policies should aim at empowering social disenfranchised people through the creation of livelihood opportunities and ensuring poor people access to social resources such as education and labour. In addition, the publication of the Human Development Index (HDI) by the United Nations Development Programme (UNDP) in 1990 further brought to attention the need to focus development policies on developing human capabilities. The HDI is a composite index which assesses elements of basic human development in a country measured by percentage enjoying decent standard of living and life expectancy at birth. This measure also includes the level of adult literacy measured by factors such as primary, secondary, and gross enrollment ratio in a country. This HDI revealed appalling records in most developing countries which signified development approaches cannot only be focusing on economic growth without the concern for human growth (Telfer, 2009; UNDP, 1999). Desai and Potter (2002) conceived development in this sense to be synonymous with promoting human rights and welfare with the purpose to enhance self-esteem, and self-respect for poor people. 


\section{PRO-POOR TOURISM: CRITICAL PERSPECTIVE AND IMPLICATIONS FOR FUTURE RESEARCH 27}

The need to focus development strategies on human development issues and not just on economic growth has been observed to influenced how tourism can also be pursed to meet the needs of the poor between the 1980s and the 1990s (Telfer, 2009). Alternative approaches to tourism development in ways to bring benefits to poor people and communities were emphasized. These include community participation, local empowerment, and equity in tourism development (Brohman, 1996; Scheyvens, 2007). At the same time, development agencies such as the World Bank and the International Monetary Fund (IMF) focused on tourism and other development approaches to help developing nations out of poverty and indebtedness in the 1990s through financial aids (Brohman, 1996; Harrison, 2008; Spenceley \& Meyer, 2012). These financial aids sponsored alternative development initiatives such as grassroots development, empowerment and community-based tourism (CBT) (Spenceley \& Meyer, 2012, p. 300 after Cole, 2006; Sofield, 2003; Zhao \& Ritchie, 2007). However, the financial aids come along with neoliberal economic conditions of deregulation, privatization, and economic rationalization (Spenceley \& Meyer, 2012; Scheyvens, 2007). In practical terms, these neoliberalism policies limit the development role of the state in favour of market forces (Tenneberg et al., 2014; Cerny, Menz, \& Soederberg, 2005; Larner, 2000; Cotoi, 2011; Scheyvens, 2009). In this context, tourism was promoted and developed as a private sector initiative in debt stricken developing countries that accepts financial aids from the IMFand the World Bank (Harrison, 2008; Mowforth \& Munt, 2016; Brohman, 1996). Like the previous approaches to tourism development, scholars note the alternative approaches of tourism rather satisfy the economic interests of local elites and their associates (Scheyvens, 2007). The objectives of tourism's alternative approaches as argued cannot be achieved under the influence of neo-liberal development market ideology. Instead the role of the state and institutions are needed to prioritized local community needs (Scheyveyns, 2007).

Viewing the challenges that hinder tourism impacts in communities, post-structuralists argued for a holistic review of structures, processes, systems, places, functions of tourism as well as an understanding of how power relations between stakeholders limits the development role of tourism (Burns, 2004; Teo, 2003; Cheong \& Miller, 2000). Post-structuralists studies resist categorizing tourism as a potential source for a blessing or a curse (Spenceley \& Meyer, 2012; Scheyvens, 2007). Instead, post-structuralists as in the work of Spenceley and Meyer emphasized that:

Rather than viewing tourism simply as an industry aligned to neo-liberal thinking, tourism [should be] perceived as a powerful social force that needs to be better understands in order to connect it more effectively to development agendas that go beyond purely economic considerations. (2012, p. 3001)

In view of the above perspectives and concerns to addressing rising global poverty in the 1990s, tourism direct linked with poverty reduction emerges as development agencies, donor, international, and non-governmental organizations which began to consider tourism as a potential means for poverty reductions for poor and developing countries (Spenceley \& Meyer, 2012). The UK Department for International Development (DFID) further commissioned research on how outbound tourism from the UK could contribute to poverty alleviation in tourists' communities (Spenceley \& Meyer, 2012). The research report recognized tourism as significant economic sector in poor countries, besides its relevance to become a source for livelihood opportunities for people in poor destinations (Harrison, 2008; Spenceley \& Meyer, 2012). Emerging from this research report was the concept of pro-poor tourism. 


\section{Some Characteristics of Pro-Poor Tourism}

PPT is not a theory or a model, neither is it dependent on development theories based on modernization, underdevelopment, or neoliberal theories as claimed by critiques. Rather, PPT is an approach to any type of tourism development with the objective of delivering net benefits to poor people. This means PPT is not a niche about a specific type of tourism such as community based tourism. Rather any type of tourism, including mass tourism can be made pro-poor. PPT strategies are therefore required to be integrated into tourism development at destinations with the focus on local development as well as developing linkages with other sectors of local economies (Ashley et al., 2001; Ashley \& Roe, 2002; Godwin, 2008).

PPT strategies according to Ashley and Roe (2002) overlap with other approaches to tourism development, including sustainable tourism, responsible tourism, community-based tourism, and eco-tourism. Nonetheless, PPT attention to poverty reduction at all levels of intervention is noted to be its most distinguishing characteristics. The same authors further argued that although community-based tourism, responsible, sustainable, and eco-tourism initiatives are located in poor localities, their main focused have mostly been on environmental conservation. It is also recognized that most community-based, responsible, sustainable, and ecotourism initiatives can become good examples of PPT strategies but PPT "is more of perspectives, [which] prioritizes and highlights impacts on the poor” (Ashley \& Roe, 2002, p. 63).

\section{Empirical Works on PPT and Impacts on Poverty Reduction}

Since the emergence of PPT, scholars have assessed a number of pro-poor tourism interventions in various communities and in different parts of the world. Some of these projects were assessed from the pro-poor tourism perspective, while others only revealed the intension of applying PPT perspective. This section reviews scholarly works on PPT to understand the present state of literature on PPT.

The reviews begin with the Nam Ha Ecotourism Project (NHEP) which has often been regarded as one of the most successful pro-poor tourism initiatives (Harrison \& Schipani, 2007). The Nam Ha Ecotourism Project was located in the Luang Namtha, in the province of Luang Namtha in Laos on the border to China. The biosphere of the province consists of different habitats and biodiversity, including river valleys, plains, and high lands. NHEP objective was to conserve the forest eco-system of the region designated as a National Protected Area. As a consequence, locals were trained to provide treks and boat trips to ethnic minority villages. Some were trained and employed to monitor threats to the biodiversity of the province. Others operated village based lodges and forest camps (Harrison \& Schipani, 2007; UNDP, 2012). The NHEP evaluators recognized the initiative has improved the local economy of 57 villages and 3,451 families through income earnings, besides its broader economy impact on the country. The project further ensured community participation, including women and ethnic minorities. On policy impact, the project was identified as a model for tourism development and elaborated in the country's National Growth and Poverty Eradication Plans (UNDP, 2012).

Mahony and Zyl (2010) further observed the success of PPT in some communities in South Africa, where PPT initiatives are been driven by the state, the private sector, and local communities. Their assessments focused on three case studies, two of which were located in the Northern Province of the country, and the other on the West Coast. The Makuleke Tourism Initiative is one of the initiatives in the Northern Province, which has a population of about 15,000 people. Attractions of the locality include the Kruger National Park, besides a scenery weather, and cultural attractions. Here, PPT development focuses on community based tourism, in 
particular environmental conservation, and funded by the South African government and donors. The second PPT assessed in the Northern Province is the development of the Manyeleti Game Reserve which is also a community based tourism initiative focusing on environmental conservation. According to Mahony and Zyl (2010), the two projects have impacted on the people of the Northern Province in several ways. These include employment of locals in small and medium scale enterprises some of which are not related to tourism. This suggests a link was developed between tourism and other sectors. Capacity building of locals to enable them participate in economic activities was also observed. The assessments claimed tourism has the potential to further maximize tourism benefits in the community overtime.

The third PPT initiative assessed by Mahony and Zyl (2010) regards the development of Umngnazi River Bungalows resort which is located in the Transkei Wild Coast. The community has a population of about 2,000 people and a diverse range of natural and cultural attractions. The resort as observed has impacted on the community in various ways. Some of these impacts include employment of some community members in various sections. In addition, the resort management financed construction of standpipes at different locations in the community. This PPT has also resulted in linkages with local entrepreneurs engaged in cultivating of vegetables, fresh fish, shellfish, crafts, and other locally produced goods. These benefits according to Mahony and Zyl (2010) fostered family unity and a sense of communal living within the community.

Further pro-poor tourism projects have been observed in enabling local residents to earn income from touristic businesses and engagement within the informal economies in Africa, South America, and the Caribbean (Ashley et al., 2001). In some destinations, women were the most beneficiaries through the sales of handicrafts which increased their financial independence (Ashley et al., 2001). PPT development has been reported to enhance opportunities for the poor in Nepal through improvement in infrastructure development such as water systems, electricity, irrigation system, and increasing access to education as in Namibia communities (Ashley et al., 2001).

Despite the favourable impacts of PPT on poverty reduction observed, its success has been limited in some destinations. Muganda et al. (2010) found tourism initiatives provide income generating opportunities for the poor while also enhancing access to improve infrastructure in the form of road networks, telecommunication, internet provision, and accessibility in the Barabarani village in Tanzania. However, Muganda et al. (2010) discovered some locals were not able to participate in tourism economic activities. Structural problems such as lack of education attainment, skills, and capital were identified as barriers.These barriers according to the authors are consistent with similar studies by Timothy (1999), Kulindwa (2002), Manyara and Jones (2007), Kibicho (2004), Rogerson (2002) in other least developed and East Africa countries.

Similarly, Suntikul, Bauer, and Song (2009) analyzed that PPT development in Viengxay, Laos deviated from its intent of empowering the local people through economic and non-economic means as compared to the Nam Ha Tourism Project in the same country. Lack of skills attainment was identified as one of the main problems that made it impossible for local people to engage in tourism entrepreneurial activities. It was also noted that the private entrepreneurs in charge of poor tourism projects lacked the required knowledge and skills about how exactly pro-poor tourism can be pursued. Leakages of tourism revenue are another problem hampering the prospects of tourism impacts on poverty reduction in some localities. For example, Akama and Kieti (2009) observed leakages of financial benefits by commercial companies assisting in tourism development in Kenya. Revenue leakages were further noted in the Okavango Delta in Botswana by foreign entrepreneurs in tourism development (Mbaiwa, 2005). 


\section{PRO-POOR TOURISM: CRITICAL PERSPECTIVE AND IMPLICATIONS FOR FUTURE RESEARCH}

In the case of Ghana, Holden, Sonne, and Novelli (2011) it examined that tourism development in Elimina has not helped in reducing poverty in the community. Nonetheless, the authors note tourism has much potential for local economic development in the Elimina community. Lack of access to micro-credit and entrepreneurial skills, exclusion from decision-making, and inflexible bureaucratic procedures are some of the problems that made it difficult for the local people to participate in tourism activities. In terms of the broader impact of tourism development in Africa, Holden et al.(2011) argued tourism has not been successful in reducing poverty. They attributed this failure to the dominance of private entities in the tourism sector and reluctance of African governments to actively engage in tourism development in local communities. Goscón (2014) applied PPT approach to tourism development in Amantani Island, Peru and found tourism only benefited few private individuals with the resources to provide services such as lodging and transportation to tourists. Due to their resources and capitals, these private individuals succeeded in influencing the tourism market and tourism decisions to increase their financial position. According to Goscón (2014), other residents are engaged in the sale of handicrafts but cannot earn as much as private individuals that control tourism business to their advantage. Differences in income earns by various groups from tourism is considered to entrenched socio-economic difference on the island.

As analyzed, the assessments impacts demonstrate PPT development has not been completely successful at destinations. At the same time, much of these assessments have rarely articulated how products are developed to become avenue for poverty reduction. Nonetheless, PPT continues to experience challenges in delivering net benefits to the poor. The lack of complete success of PPT at destinations has rather resulted in reductionist argument between PPT proponents and critiques, where PPT is ether regarded as a force for good or as a force for evil based on PPT success and failures or challenges at destinations (Ashely et al., 2001; Godwin, 2008; Meyer, 2009; Harrison, 2008; Scheyvens, 2009). Meanwhile, products developments as already mentioned have been regarded as essential in making tourism contribute to lessen economic challenges of the poor, but have not been the main focus of PPT's scholarly works. It is in this respect that this study emerged to argue for scholarly works to focus on products development to understand how PPT can influence poverty reduction in a more effective way at destination within the current global development phase regarded as post-capitalism which consists of competing interests of stakeholders in tourism development.

However, it is understood from the destination development literature that products developments are much influenced by the destination's characteristics and how these are interpreted to and by consumers. This interpretation has been done in different ways by different scholars. It is therefore important to discuss the destination concept to identify its important components to establish its significance for pro-poor tourism and implications for future research.

\section{Clarifying the Destination Concept in Tourism}

Destination is the most commonly used concept in tourism but has often been used to mean different things, in particular "as a narrative, as an attraction, as a geographical unit, as an empirical relationship, as a marketing object, [and] as a place where tourism happens” (Framke, 2002, p. 93). However, Buhalis (2000, p. 97) broadens the scope of the destination concept by viewing it as "amalgams of tourism products, offering an integrated experience to consumers". Buhalis (2000) further clarifies that destinations consist of combined

elements of products, services, and experience offered locally as a brand. These combined elements include attractions, accessibility, amenities, destination activities, ancillary services, and available packages by 
intermediaries (Buhalis, 2000). Laws (1995) categorizes destination elements into primary and secondary resources. The former consists of climate, ecology, traditions, and architecture while the latter includes facilities developed to satisfy tourist experiences. Earlier, Middleton (1998) called these destination determinants as Total Tourism Products (TTP), where TTP includes natural and man-made attractions such as destination attractions and facilities, accessibility routes, and images for marketing destinations. Tinseley and Lynch (2001) acknowledged that destinations consist of geographical attractions, communities and places with residents, services, and businesses where interaction between economic and non-economic actors transpires (Tinseley \& Lynch, 2001). Carlsen (1999) conceptualizes destinations as interacting or co-producing systems of economic, social and geographical elements in tourist locations. An understanding on the destination concept could therefore mean an entity comprising of variety of elements for touristic purposes.

When it comes to developing destinations, Laws (1995) emphasizes that destination development passes through two phases, namely, pre-tourism phase and tourism management phase. The pre-tourism phase consists of two additional sub-phases where in the first sub-phase the destination is regarded as a primary unit visited by friends from the destination's locality for business purposes and fulfills family obligations. The second sub-phase occurs when stakeholders consider transforming the destination to attract visitors for touristic reasons, besides visit by family, friends, and those in businesses. Tourism management phase, which is the second phase, according Laws (1995) is the phase at which the destination developers implement initiatives to improve the quality of tourism products and services at the destination. In this case, it is suggested that processes involved in tourism development could focus on the development of resources at the destination, including natural and cultural resources as well as the political and legal systems of the country to attract consumers (Manhas, Manrai, \& Manrai, 2016). Offering a memorable and satisfy experiences to consumers, is one of the main objectives of tourism at destinations (Law, 1995). Usually, the creation of touristic experiences has been the responsibilities of destination marketers, service providers, and other tourism stakeholders (Manhas et al., 2016). However, since consumer satisfaction is an important aspect of destination development, tourists are now considered as co-creators of touristic experiences (Prahalad \& Ramaswamy, 2004; Manhas et al., 2016).

In addition, the development of infrastructure as well as touristic facilities is required to make the destination attractive to consumers (Law, 1995). Therefore governments have roles in developing destination's infrastructure (PPTP, 2004). For further benefits of tourism in localities, recruitments and training of staffs are needed (Laws, 1995). These developments could have essential impacts in local economies as well as contributing to the overall development of the destination (Nagle, 1999). To further ensure destinations becoming important means for marketing of goods and services, destination marketing is considered important to achieve this goal (Laws, 1995). Destination marketing will attract visitors to further "provide the economic demands needed by all the area's tourism businesses” (Laws, 1995, p. 104). However, destination branding has been regarded the effective means to ensure marketing has the desired impact on consumers (Kladou, Kavaratzis, Rigopoulo, \& Salonika, 2017; Manhas et al., 2016; Laws, 1995). Destination branding gives a favourble impression about destinations, besides differentiation from competing destinations (Souiden, Ladhari, \& Chiadmi, 2017). Branding further helps to position products to attract specific groups of tourists (Aaker, 1991; Baloglu \& Brindberg, 1997; Cai, 2002). Branding thus aims to influence tourists' intent and preference to visit a particular destination as well as stimulating tourists mental and emotional expectations prior to visiting a preferred destination (Kladou et al., 2017; Souiden et al., 2017; Manhas et al., 2016). 
Although branding plays a role in attracting visitors to destinations, its influential impacts on tourists depends on the kind of brand image created about the destination. For this reason, the creation of a preferable brand images about destinations has been emphasized (Ashton, 2014; Kladou et al., 2017). A brand image can be a construct of cognitive and affective images associated with destinations. The cognitive aspect defines physical attributes of the destination whereas the affective dimension concerns emotional thoughts or memory aroused by destination's physical attributes (Baloglu \& McClearly, 1999). Stimuli combination of both cognitive and affective of brand images can be inspired by the landscape and physical attributes of the destination, including cultural stimuli, and other non-cultural elements that may appeal to consumers (Kladou et al., 2017). Irrespective of the content of brand images, the symbolic and positive attributes of destinations are important to be revealed because of their influential impacts on tourism consumers (Ashton, 2014; Padgett \& Allen, 1997).

The final section that follows discussed the relevance of the above conceptual discussion for products development in pro-poor tourism with implications for further research

\section{Discussion, Conclusions, and Further Research}

One of the concerns in the paper is that the success of pro-poor tourism development could depend on how tourism with respect to products is developed at destinations. As already explore, products development is one of the means for tourism to become an avenue for economic and non-economic opportunities for local residents. This need for product development has earlier been highlighted by Ashley and Roe (2002, p. 74) as they stressed that "If pro-poor tourism initiatives are to be commercially successful, they need to succeed in competitive tourism markets. Whether they can do this well depends on the products they offer, their location and effective marketing” (Ashley \& Roe, 2002, p. 74). This implies that for tourism to become pro-poor, practical strategies have to be developed and applied by those concerned with PPT development. Requirement of practical strategies by actors in tourism development to influence poverty reduction including the private sector governments, and academia have been emphasized (Spenceley \& Meyer, 2012). This focus on product development may consider contingent elements necessary for tourism development at destinations, including the development process of touristic facilities, available products, necessary infrastructure as well as strategies employed in marketing and branding of destinations where necessary. This means PPT scholarly works cannot be overly concerned with tourism impacts on poverty reduction without understanding how destinations are develop to become a source that can deliver net benefits for poor local residents. This implies the processes by which products are developed have to be considered by researchers in order to understand if destinations have the capacity to support pro-poor growth. Strategies of stakeholders in tourism development can be examined in order to understand how products are developing to become competitive and means for economic and non-economic livelihoods in communities. These strategies can be explored at any of the stages involved in destination development. That is, either at the pre-tourism phase or at the tourism management phase as discussed. Besides, investigating economic viability of destinations can be done to understand the effectiveness of PPT to support income generating activities for locals. This is necessary because PPT thrives better in destinations that can support markets for goods and services as claimed (Ashley et al., 2001; Ashley \& Roe, 2002). The work of Laws (1995) for example can be relevant for pro-poor tourism researchers by focusing on varieties and quality of activities, amenities, and administrative measures taken to attract visitors to destinations. Laws (1995) further assets specific ways to investigate economic viabilities of destinations. In the first place, 


\section{PRO-POOR TOURISM: CRITICAL PERSPECTIVE AND IMPLICATIONS FOR FUTURE RESEARCH 33}

researchers may investigate the relevant elements of tourism products at destinations to determine their potentials of attracting visitors and becoming a source of livelihood for local residents. Such products could be primary, secondary, natural, or cultural products. Secondly, auditing of tourism facilities to assess quality and capacity of resources, and pricing policy. The third step requires investigating how tourists used destinations resources through surveys and determining the facilities used mostly. These considerations raised for products development may help PPT "practitioners to recognize the value of, for example, improvements in infrastructure or access to communication, and to identify areas of untapped potential”, such as developing linkages (Ashley \& Roe, 2002, p. 79). The paper encourages researchers to move PPT scholarship beyond assessment impacts on poverty reductions to focus on capacity of destinations in providing opportunities for the poor with recommendations to improve PPT development and accelerate impact on poverty reduction. This reinforces the broader discussion of taking scholarly research on tourism and poverty reduction that focuses on impact assessments to examine development processes involved with measures that can "expedite poverty reduction through tourism” (Spenceley \& Meyer, 2012, p. 311).

\section{References}

Aaker, D. (1991). Managing brand equity: Capitalizing on the value of a brand name. New York: Free Press.

Akama, J. S., \& Keitu, K. (2009). Tourism and socio-economic development in developing countries: A case study of Mombasa resort in Kenya. Journal of Sustainable Tourism, 15(6), 735-748.

Anderson, W. (2015). Cultural tourism and poverty alleviation in rural Kilimanjaro, Tanzania. Journal of Tourism and Cultural Change, 13(3), 208-224.

Ashton, A. S. (2014). Tourist destination brand image development—an analysis based on stakeholders' perception: A case study from Southland, New Zealand. Journal of Vacation Marketing, 20(3), 279-292.

Ashley, C., \& Godwin, H. (2007). "Pro-poor tourism”: What's gone right and what's gone wrong. Opinion. Overseas Development Institute.

Ashley, C., \& Roe, D. (2002). Making tourism work for the poor: Strategies and challenges in Southern Africa. Development Southern Africa, 19(1), 61-82.

Ashley, C., Roe, D., \& Godwin, H. (2000). Pro-poor tourism: Putting poverty at the heart of tourism agenda. Natural Resource Perspectives. Number 51. London: Overseas Development Institute.

Ashley, C., Dilys, R., \& Godwin, H. (2001). Pro-poor tourism strategies: Making tourism work for the poor: A review experience. Pro-Poor Tourism Report No. 1. London: Overseas Development Institute.

Baloglue, S., \& Brinberg, D. (1997). Affective image of tourism destination. Journal of Travel Research, 35(4), 11-15.

Baloglu, S., \& McCleary, K. W. (1999). A model of destination image formation. Annals of Tourism Research, $26(4), 868-897$.

Beer, A.D., \& Beer, F.D. (2011). Reflections on pro-poor tourism in South Africa: Challenges of poverty and policy in the search for a way forward. Journal of Contemporary Management, 8, 591-606.

Brohman, J. (1996). New directions in tourism for third world development. Annals of Tourism Research, 23(1), 48-70.

Burns, M. P. (2004). Tourism planning a third way? Annals of Tourism Research, 31(1), 24-43.

Buhalis, D. (2000). Marketing the competitive destination of the future. Tourism Management, 21, 97-116.

Britton, S. (1982). The political economy of tourism in the third world. Annals of Tourism Research, 9(3), 331-358.

Carlsen, J. (1999). A system approach to Island tourism destination management. System Approach and Behavioural Science, 16, 321-327.

Cai, A. (2002). Cooperative branding for rural destinations. Annals of Tourism Research, 29(3), 720-742.

Cerny, P., Menz, G., \& Soederberg, S.(2005).Different roads to globalization: Neoliberalism, the competition state, and politics in a more open world. In S. Soederberg, G. Meenz, and P. Cerny (Eds.), International globalization. The rise of neoliberalism and the decline of national varieties of capitalism (pp.1-32). UK: Palgrave.

Cheong, S., \& Miller, M. (2000). Power and tourism: A foucauldian observation. Annals of Tourism Research, 27(2), 371-390.

Cole, S. (2006). Information and empowerment: The keys to achieving sustainable tourism. Journal of Sustainable Development, 14(6), 629-644. 


\section{PRO-POOR TOURISM: CRITICAL PERSPECTIVE AND IMPLICATIONS FOR FUTURE RESEARCH}

Cotoi, C. (2011). Neoliberalism: Foucauldian perspective. International Review of Social Research, 1(2), 109-124.

Chok, S., Macbeth, J., \& Warren, C. (2007). Tourism as a tool for poverty alleviation: A critical analysis of pro-poor tourism and implications for sustainability. Current Issues in Tourism, 10(2-3), 144-165.

Croes, R. (2014). The role of tourism in poverty reduction: An empirical assessment. Tourism Economics, 20(20), 207-226.

Desai, V., \& Potter, R. (2002). The nature of development and development studies. In V. Dessai and R. B. Potter (Eds.), The companion to development studies (pp.1-2). New York: Oxford University Press.

De Kadt, E. (Ed.) (1979). Tourism passport to development? New York: Oxford University Press.

Framke, W. (2002). The destination as a concept: A discussion of the business-related perspective versus the socio-cultural approach in tourism theory. Scandinavian Journal of Hospitality and Tourism, 2(2), 92-108.

Fletcher, J. (2009). Economics of international tourism. In T. Jamal and M. Robinson (Eds.), The sage handbook of tourism studies (pp. 168-187). London: Sage.

Friedman, J. (1992). Empowerment: The politics of alternative development. Blackwell: Cambridge.

Gascón, J. (2014). Pro-poor tourism as a strategy to fight rural poverty: A critique. Journal of Agrarian Change, 15(4), 499-518.

Godwin, H. (2008). Tourism, local economic development, and poverty reduction. Applied Research in Economic Development, 5(3), 55-64.

Harrison, D. (2008). Pro-poor tourism: Acritique. Third World Quarterly, 29(5), 851- 868.

Harrison, D., \& Schipani, S. (2007). Lao tourism and poverty alleviation: Community-based tourism and the private sector. Current Issues in Tourism, 10(2-3), 194-230.

Holden, A., Sonne, J., \& Novelli, M. (2011). Tourism and poverty reduction: An interpretation by the poor in Elmina. Tourism Planning and Development, 8(3), 317-334.

Hummel, J., \& van der Duim, R. (2012). Tourism and development at work: 15 years of tourism and poverty reduction within the SNV Netherlands Development Organization. Journal of Sustainable Tourism, 20(3), 319-338.

Kladou, S., Kavaratzis, M., Rigopoulo, I., \& Salonika, E. (2017). The role of brand elements in destination branding. Journal of Destination Marketing \& Management, 6, 426-435.

Kibicho, W. (2004). Community tourism: A lesson from Kenya’s Coastal Region. Journal of Vacation Marketing, $10(1), 33-42$.

Laws, E. (1995). Tourist destination management: Issues, analysis and policies. London and New York: Routledge.

Larner, W. (2000). Neoliberalism: Policy, ideology or governmentality. Studies in Political Economy, 63, 5-25.

Medina-Muñoz, D. R., Medina-Muñoz, R. D., \& Gutierrez-Perez, F. J. (2016). The impacts of tourism on poverty reduction: An integrated research framework. Journal of Sustainable Tourism, 24(2), 270-298.

Manwa, H., \& Manwa, F. (2014). Poverty alleviation through pro-poor tourism: The role of Botswana Forest Reserves. Sustainability, 6, 5697-5713.

Marzuki, A. (2012). Local residents' perception towards economic impacts of tourism development in Phuket. Tourism-An Interdisciplinary Journal, 60(2), 199-212.

Manhas, S. M., Manrai, L. A., \& Manrai, A. K. (2016). Role of tourist destination development in building its brand image: A conceptual model. Journal of Economics, Finance and Administrative Science, 21, 25-29.

Mahony, K., \& Van Zyl, J. (2002). The impacts of tourism investment on rural communities: Three case studies in Southern Africa. Development of Southern Africa, 19(1), 83-108.

Marks, S. P., \& Andreassen, B. A. (2006). Introduction. In B. A. Andreassen and P. M. Stephen (Eds.), Development as human right (pp.vi-xxii). Cambridge, MA: Havard University Press.

Middleton, V. T. C. (1998). Marketing in travel and tourism. Oxford: Heinemann.

Munganda, M., Sahli, M., \& Smith, K. A. (2010). Tourism’s contribution to poverty alleviation: A community perspective from Tanzania. Development Southern Africa, 27(5),629-646.

Mabaiwa, J. E. (2005). The problems and prospects of sustainable tourism development in the Okavango Delta, Botswana. Journal of Sustainable Tourism, 13(3), 2003-2227.

Manyara, G., \& Jones, E. (2007). Community-based tourism enterprises development in Kenya: Three case studies in South Africa. Development Southern Africa, 19(1), 83-103.

Mawforth, M., \& Munt, I. (2016). Tourism and sustainability: Development, globalization and new tourism in the Third World. London: Routledge.

Meyer, D. (2009). Pro-poor tourism: Is there actually much rhetoric? And, if so, whose? Tourism Recreation Research, 34(2), 197-199.

Nagle, G. (1999). Tourism, leisure and recreation. Surrey: Thomas Nelson and Sons Ltd. 


\section{PRO-POOR TOURISM: CRITICAL PERSPECTIVE AND IMPLICATIONS FOR FUTURE RESEARCH 35}

Padgett, D., \& Allen, D. (1997). Communicating experiences economy: A narrative approach to creating service brand image. Journal of Travel Research, 42, 333-342.

Pedrana, M. (2013). Local economic development and tourism: An approach to sustainability and culture. Regional Science Inquiry, 1, 91-99.

Prahalad, C. K., \& Ramaswamy, V. (2004). Co-creation experiences: The net practice in value creation. Journal of Interactive Marketing, 18(3), 5-14.

Pro-Poor Tourism Partnership (PPTP) (2004). Overview of pro-poor tourism strategies. Sheet No.2 PPTStrategies.

Rogerson, C. M. (2002). Tourism and local economic development: The case of the Highland Meander. Development Southern Africa, 9(1), 143-167.

Rostow, W. W. (1960). The stages of economic growth: A comparative manifesto. Cambridge: Cambridge University Press.

Scheyvens, R. (2007). Exploring the tourism-poverty Nexus. Current Issues in Tourism, 10(2-3), 231-254.

Scheyvens, R. (2009). Pro-poor tourism: Is there value beyond the rhetoric? Tourism Recreation Research, 34(2), $191-196$.

Sharma, K. K. (2004). Tourism and economic development. New Delhi: Sarup and Sons.

Sharpley, R. (2010). Tourism and sustainable development: Exploring the theoretical divide. Journal of Sustainable Tourism, 8(1), $1-19$.

Sharpley, R., \& Naidoo, P. (2010). Tourism and poverty reduction: The case of Mauritius. Tourism and Hospitality Planning \& Development, 7(2), 145-162.

Suntikul, W., Bauer, T., \& Song, H. (2009). Pro-poor tourism development in Viengxay, Laos: Current state and future prospects. Asia Pacific Journal of Tourism Research, 14(2), 153-168.

Sofield, T. (2003). Empowerment for sustainable tourism development. Oxford: Elsevier.

Souiden, N., Ladhari, R., \& Chiadmi, N. E. (2017). Destination personality and destination image. Journal of Hospitality and Tourism Management, 32, 54-70.

Spenceley, A., \& Meyer, D. (2012). Tourism and poverty reduction: Theory and practice in less economically developed countries. Journal of Sustainable Tourism, 20(3), 297-317.

Timothy, D. J. (1999). Participatory planning: A view of tourism in Indonesia. Annals of Tourism Research, 26(2), $371-391$.

Telfer, D. J. (2002). The evolution of tourism and development theory. In R. Shaarpley and D. J. Telfer (Eds.), Tourism and development: Concepts and issues (pp. 35-78). Clevedon: Channel View Publications.

Telfer, D. J. (2009). Development studies and tourism. In T. Jamal and M. Robinson (Eds.), The sage handbook of tourism studies (pp. 146-165). Sage: London.

Tenneberg, B., Vola, J., Espiritu, A. A., Fors, B. S., Ejdemo, T., Riabova, L., Korchak, E., Tonkova, E., \& Nosova, T. (2014). Neoliberal governance sustainable development and local communities in the Barents Region. Barents Studies, 1, 41-72.

Tinsley, R., \& Lynch, P. (2001). Small tourism business networks and destination development. Hospitality Management, 20, 367-378.

Teo, P. (2003). Striking a balance for sustainable tourism: Implications of the discourse on globalization. Journal of Sustainable Tourism, 10(6), 45-474.

United Nations-World Tourism Organization (UNWTO) (2017). Making tourism a tool to fight poverty: Ten years of ST-EP initiative. Retrieved from http://www.http//cf.cdn.unwto.org (accessed on October 6, 2018).

United Nations Development Programme (UNDP) (1999). Human Development Report1999. Retrieved from http://www.hdr.undp.org (accessed on October 1, 2018).

United Nations Development Programme (UNDP) (2012). Nam Ha Ecotourism Projects, Lao PDR. New York: Equator Initiative Case Study Series.

Zhao, W., \& Ritche, J. R. (2007). Tourism and poverty alleviation: An integrative research framework. Current Issues in Tourism, 10(2-3), 119-143. 